\title{
FAKTOR - FAKTOR PENENTU KEPUTUSAN PETANI SAWAH KE PERIKANAN DI DESA LIMAN SARI BUAY MADANG TIMUR KABUPATEN OKU TIMUR
}

\author{
(Sudarti)
}

\begin{abstract}
The purpose of this research were to : (1) Analyze the factors that influence farmers to transfer rice paddy fields to fishing commodities, (2) Counts how differences in income received by households of farmers of paddy rice over to fishery commodities. This research was conducted in the village of Sari Liman Eastern District of Buay Madang East Ulu Ogan Ogan. The location determination is done intentionally (purposive), from 28 villages in the District Buay Madang East only village Liman Sari selected researchers to conduct research on over commodity rice paddy fields to fishing with the consideration that the village catfish production of the highest and the land area widest among other villages. Collecting data on the location of the research conducted in March and June 2013. The study found that the factors that influence household decisions to transfer commodity farmers in rice paddy fields to fishing at test level to 20\%, ie farmers' income (4.3\%), the number of production (12.9\%) and the risk of farming (12.6\%), while the area of land owned no real effect, and the results of statistical analysis using Wilcoxon sign test analysis, the obtained value Zhitung $=-5.373<$ Ztabel with $p$ value (Asymp sign 2 tailed $)=0.000$ which is less than the critical value of 0.05 research. This indicates that the income of farmers who perform over paddy rice commodity to larger catfish farming is $R p$ 94,833,642, - per year per hectare than rice paddy farming income that does not do over the function of the land is $R p 25,154,791$, - per year per hectares.
\end{abstract}

Key Words : Land Transfer Function, Farming Sciences, and Income.

\section{PENDAHULUAN}

\section{A. Latar Belakang}

Alih fungsi lahan pertanian di Indonesia sulit dibendung. Luas lahan yang terkonversi tidak mampu diimbangi dengan ekstensifikasi melalui pembukaan sawah baru. Lahan produktif untuk pangan pun kian defisit. Selain itu, harga produk pertanian di Indonesia khususnya beras pada tingkat petani dihargai sangat rendah, sangat berbeda dengan petani di negara lain seperti Jepang, Korea, maupun negara serumpun Malaysia. Menstabilkan harga beras di ranah petani dengan harga pasar tradisional akan menjadikan petani lebih sejahtera dan mempunyai inisiatif untuk berproduksi dan meningkatkan produktivitas. Setidaknya tidak lagi memikirkan untuk melakukan pengalihfungsian lahan karena kebutuhan primer mereka sudah tercukupi (Nita, 2014).

Luas lahan sawah di Provinsi Sumatera Selatan tahun 2009 adalah 611.386,00 hektar dengan produksi mencapai 3.272.451 ton, dan pada tahun 2012 yaitu 617.096,00 hektar dengan produksi sebesar 3.497.917 ton. Hal ini dapat dilihat pada Tabel berikut:

Tabel 1. Luas Lahan Sawah di Provinsi Sumatera Selatan Tahun 2009-2012.

\begin{tabular}{cccc}
\hline No. & Tahun & $\begin{array}{c}\text { Luas Lahan } \\
\text { (Ha) }\end{array}$ & $\begin{array}{c}\text { Produksi } \\
\text { (Ton) }\end{array}$ \\
\hline
\end{tabular}

\begin{tabular}{llll}
\hline 1 & 2010 & $611.386,00$ & 3.272 .451 \\
2 & 2011 & $629.355,00$ & 3.384 .670 \\
3 & 2012 & $617.916,20$ & 3.295 .247 \\
4 & 2013 & $612,424.00$ & 3.676 .723 \\
5 & 2014 & $617.096,00$ & 3.497 .917 \\
\hline
\end{tabular}

Sumber : Statistik Lahan Pertanian, 2012.

Berdasarkan Tabel 1, luas lahan sawah di Provinsi Sumatera Selatan setiap tahunnya mengalami fluktuasi, diduga alih fungsi lahan sawah mulai marak dilakukan oleh petani. Lahan yang dialihfungsikan itu sebagian adalah sawah kurang produktif karena hanya bisa dipanen sekali dalam setahun. Menurut Kepala Bidang Produksi Tanaman Pangan Dinas Pertanian, Tanaman Pangan, dan Hortikultura Sumatera Selatan (Komunikasi Pribadi, 2012), faktor utama alih fungsi sawah itu karena petani merasa belum sejahtera dari hasil panennya. Sawah yang dialihfungsikan ada di kawasan rawa- rawa dan pasang surut.

Untuk mencegah terjadinya krisis pangan pemerintah mengeluarkan Undang-Undang Nomor 41 Tahun 2009, penyediaan lahan pengganti Lahan Pertanian Pangan Berkelanjutan (LPPB) yang dialihfungsikan untuk kepentingan umum dilakukan atas dasar kesesuaian kesuburan lahan dengan ketentuan sebagai berikut: a) paling sedikit tiga kali luas lahan dalam hal yang dialihfungsikan lahan beririgasi b) paling sedikit dua kali lahan dalam hal yang dialihfungsikan 
reklamasi rawa pasang surut dan non pasang surut lebak c) paling sedikit satu kali luas lahan dalam hal yang dialihfungsikan lahan tidak beririgasi (Anonim, 2009).

Pemerintah Kabupaten Ogan Komering Ulu Timur (OKU Timur) Sumatera Selatan membuat Peraturan Daerah (Perda) Nomor 7 Tahun 2009 tertanggal 12 Desember 2009 untuk memperketat izin alih fungsi lahan persawahan ke non pertanian, masyarakatnya memiliki kecenderungan untuk mengalihfungsikan lahan sawahnya, dibandingkan mempertahankan areal sawahnya untuk ditanami padi, padahal kabupaten ini merupakan lumbung padi di Sumatera Selatan. Hal ini perlu segera diwaspadai karena jika tidak diantisipasi sejak dini, bukan tidak mungkin ribuan hektar sawah irigasi teknis dan sawah tadah hujan yang sebelumnya panen dua sampai tiga kali dalam setahun, justru akan berubah fungsi menjadi lahan budidaya perikanan, perkebunan dan menjadi pemukiman dengan bangunan permanen. Dalam kurun lima tahun terakhir di Kabupaten OKU Timur luas lahan padi sawah mengalami penurunan sedangkan luas lahan ikan mengalami peningkatan hal ini menunjukan bahwa puluhan hektar sawah irigasi teknis dan tadah hujan telah berubah fungsi menjadi lahan budidaya perikanan. Jenis ikan yang banyak dibudidayakan di Kecamatan Buay Madang Timur adalah jenis ikan tawar yaitu ikan patin, nila, mas, bawel dan lele (Tabel 2).

Tabel 2. Jenis Ikan yang Dibudidayakan Petani di Kecamatan Buay Madang Timur, 2012.

\begin{tabular}{llccc}
\hline No & Jenis Ikan & $\begin{array}{c}\text { Luas } \\
\text { (Ha) }\end{array}$ & $\begin{array}{c}\text { Produksi } \\
\text { (Ton) }\end{array}$ & $\begin{array}{c}\text { RTP } \\
\text { (Org) }\end{array}$ \\
\hline 1. & Nila & 337,88 & $2.032,69$ & 1.233 \\
2. & Mas & 79,87 & 430,10 & 296 \\
3. & Bawal & 75,12 & 430 & 192 \\
4. & Lele & 268,58 & $4.890,66$ & 1.995 \\
5. & Patin & 514,05 & $6.539,20$ & 905 \\
\hline
\end{tabular}

Sumber : UPTD Perikanan dan Peternakan Buay Madang Timur, 2012.

Para petani di Kecamatan Buay Madang Timur lebih banyak membudidayakan jenis ikan patin dibandingkan jenis ikan lainnya, walaupun memerlukan waktu budidaya yang lebih lama namun ikan patin lebih tahan dari serangan penyakit.

Desa Liman Sari merupakan salah satu desa yang terdapat di Kecamatan Buay Madang Timur Kabupaten OKU Timur yang tergolong paling banyak jumlah rumah tangga petani ikan patin, luas lahan, dan produksinya dibandingkan desa lainya, yaitu jumlah rumah tangga petani sebanyak 278 orang dengan luas lahan 119,29 hektar dan produksi $1.517,48$ ton setiap tahunnya.

Tabel 3. Luas lahan, Rumah Tangga Petani, dan Produksi Ikan Patin di Kecamatan Buay Madang Timur, 2012.

\begin{tabular}{|c|c|c|c|c|c|}
\hline \multirow[b]{2}{*}{ No. } & \multirow[b]{2}{*}{ Desa } & \multirow[b]{2}{*}{$\begin{array}{l}\text { Luas Lahan } \\
\text { Sawah }(\mathrm{Ha})\end{array}$} & \multicolumn{3}{|c|}{ Patin } \\
\hline & & & $\begin{array}{c}\text { RTP } \\
\text { (Orang) }\end{array}$ & $\begin{array}{c}\text { Luas Lahan } \\
(\mathrm{Ha})\end{array}$ & $\begin{array}{l}\text { Produksi } \\
\text { (Ton) }\end{array}$ \\
\hline 1. & Tanjung Mas & 405,75 & 161 & 78,47 & 988,72 \\
\hline 2. & Liman Sari & 282,5 & 278 & 119,29 & $1.517,48$ \\
\hline 3. & Sumber Harjo & 456,25 & 42 & 29,98 & 285,97 \\
\hline 4. & Sumber Mulyo & 466,5 & 19 & 17,56 & 259,25 \\
\hline 5. & Bangun Harjo & 243,75 & 17 & 15,87 & 201,54 \\
\hline 6. & Karang Tengah & 191,5 & - & - & - \\
\hline 7. & Sri Katon & 654,25 & 59 & 24,95 & 314,37 \\
\hline 8. & Tanjung Sari & 614,5 & - & - & - \\
\hline 9. & Sumber Asri & 247,25 & 8 & 2,56 & 32,51 \\
\hline 10. & Sukamaju & 798,5 & - & - & - \\
\hline 11. & Suko Harjo & 342,5 & 14 & 12,34 & 156,71 \\
\hline 12. & Tekorejo & 298 & - & - & - \\
\hline 13. & Pengandonan & 229,5 & 16 & 19,23 & 244,22 \\
\hline 14. & Tambak Boyo & 386 & 28 & 18,78 & 238,50 \\
\hline 15. & Rejodadi & 265 & - & - & - \\
\hline 16. & Rowodadi & 176,25 & 33 & 23,25 & 380,75 \\
\hline 17. & Sukodadi & 227,75 & 34 & 27,45 & 348,61 \\
\hline 18. & Sumedang Sari & 250 & 28 & 21,26 & 270,00 \\
\hline 19. & Kumpul Rejo & 234,75 & - & - & - \\
\hline 20. & Metro Rejo & 478,25 & 4 & 3,13 & 40,82 \\
\hline 21. & Kedu & 180,75 & - & - & - \\
\hline 22. & Kedung Rejo & 142 & 12 & 11,71 & 148,19 \\
\hline 23. & Banyumas Asri & 213,5 & - & - & - \\
\hline 24. & Tanjung Agung & 163,75 & - & - & - \\
\hline 25. & Tanjung Mulya & 183,5 & - & - & - \\
\hline 26. & Raman Agung & 169,5 & 152 & 88,22 & $1.111,57$ \\
\hline 27. & Bukit Mas & 295 & - & - & - \\
\hline 28 & Berasan Mulya & 181,5 & - & - & - \\
\hline & Jumlah & $8.778,25$ & 905 & 514,05 & $6.539,20$ \\
\hline
\end{tabular}

Sumber : UPTD Perikanan dan Peternakan Buay Madang Timur, 2012.

Desa Liman Sari yang berada di Kecamatan Buay Madang Timur merupakan daerah rentan akan banjir di karenakan Desa Liman Sari sebagian lahan sawahnya berada pada daerah rawa hal ini menyebabkan petani padi sawah sering mengalami kerugian. Sejak 6 tahun terakhir banyak petani pada daerah ini yang melakukan alih fungsi lahan sawah ke perikanan. Mereka beranggapan dengan beralih fungsi, lahan mereka jauh lebih berproduktif.

Komitmen pemerintah Daerah Kabupaten OKU Timur tetap menjadikan daerah ini sebagai daerah agraris atau sentra tanaman pangan. Sesuai dengan undang-undang nomor 41 tahun 2009 tentang Perlindungan Lahan Pertanian Pangan Berkelanjutan (PLP2B) sudah diatur masalah alih fungsi lahan tersebut diantaranya disebutkan, bagi mereka yang hendak alih fugsi lahan sawah irigasi teknis satu hektar harus mengganti dengan lahan yang baru seluas tiga hektar. Sedangkan jika sawah tadah hujan satu 
hektar dialihfungsikan harus diganti dengan dua hektar. Sementara lahan sawah yang selama ini tidak produktif dialih fungsikan satu hektar harus diganti dengan satu hektar juga. Untuk melaksanakan ketentuan pasal 26 dan pasal 53 Undang-Undang nomor 41 tahun 2009 tentang Perlindungan Lahan Pertanian Pangan Berkelanjutan (PLP2B), perlu menetapkan Peraturan Pemerintah nomor 1 tahun 2011 tentang Penetapan dan Alih Fungsi Lahan Pertanian Pangan Berkelanjutan. Walaupun dengan dibuatnya aturan tersebut masyarakat di Kabupaten OKU Timur alih fungsi lahan masih terus di lakukan hal ini disebabkan karena kurangnya pengetahuan petani tentang aturan alih fungsi lahan, tidak adanya penyuluhan dan kurang tegasnya pemerintah setempat mengenai aturan tersebut. Luas lahan yang alih fungsi di OKU Timur sejauh ini belum begitu luas, namun jika dibiarkan terus terjadi mungkin luasnya akan bertambah.

\section{B. Rumusan Masalah}

1. Faktor-faktor apa saja yang mempengaruhi rumah tangga petani melakukan alih komoditi padi sawah ke perikanan.

2. Berapa perbedaan pendapatan yang diterima rumah tangga petani dari alih komoditi padi sawah sawah ke perikanan.

\section{Tujuan dan Kegunaan}

1. Menganalisis faktor-faktor apa saja yang mempengaruhi petani melakukan alih komoditi padi sawah ke perikanan.

2. Menghitung berapa perbedaan pendapatan yang diterima rumah tangga petani dari alih komoditi padi sawah ke perikanan.

\section{Model Pendekatan}

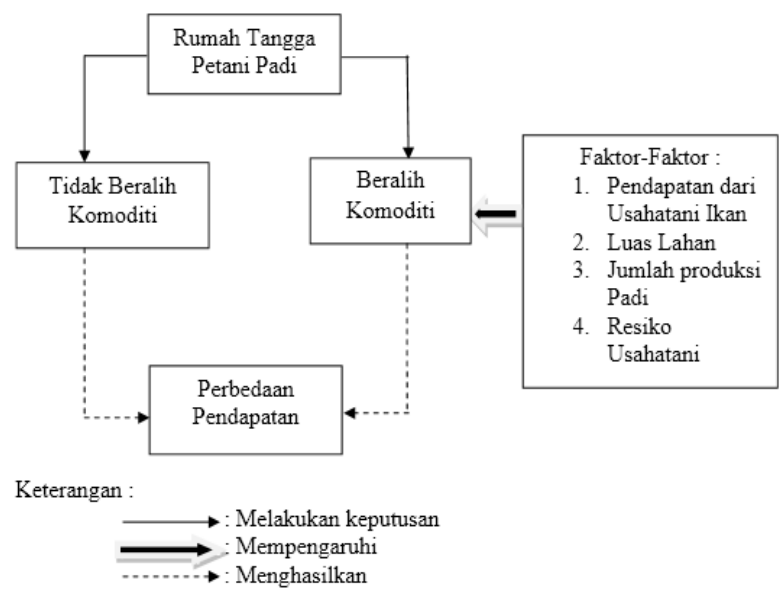

Gambar 1. Model pendekatan penelitian secara diagramatik.

\section{METODOLOGI PENELITIAN}

\section{A. Tempat dan Waktu}

Penelitian ini telah dilaksanakan di Desa Liman Sari Kecamatan Buay Madang Timur Kabupaten Ogan Komering Ulu Timur. Penentuan lokasi dilakukan secara sengaja (purposive), dari 28 Desa di Kecamatan Buay Madang Timur hanya Desa Liman Sari yang dipilih peneliti untuk melakukan peneliti tentang alih komoditi padi sawah ke perikanan dengan pertimbangan bahwa di desa tersebut produksi ikan patin yang tertinggi dan dengan luas lahan terluas diantara desa-desa lain. Pengumpulan data di lokasi penelitian dilaksanakan pada bulan Maret sampai dengan Juni 2013.

\section{B. Metode Penelitian}

Metode yang digunakan dalam penelitian ini adalah metode studi kasus. Metode studi kasus adalah metode penelitian yang mengambil sampel dari populasi terbanyak yang melakukan alih komoditi padi sawah ke perikanan, karena tidak semua desa petaninya melakukan alih komoditi padi sawah ke perikanan, sehingga penelitian ini dilakukan dengan metode kasus dengan sampel petani di Desa Liman Sari Kecamatan Buay Madang Timur Kabupaten Ogan Komering Ulu Timur.

\section{Metode Penarikan Contoh}

Metode penarikan contoh yang digunakan adalah metode acak berlapis tidak berimbang (Disproportionate Stratified Random Sampling). Teknik ini dilakukan dengan membagi-bagi populasi menjadi sub populasi atau strata dan dari setiap strata tersebut dipilih satuan pengamatan secara random dengan atau tanpa pengembalian pada masing-masing kelompok tersebut ( Nasir, 2009).

\section{Metode Pengolahan Data}

Data yang telah diperoleh dari lapangan diolah secara matematis, disajikan secara tabulasi dan untuk menjawab tujuan pertama, yaitu menganalisis faktor-faktor apa saja yang mempengaruhi petani melakukan alih komoditi padi sawah ke perikanan, maka dapat dilakukan analisis dengan menggunakan pendekatan model logit (Sugianti, 2010) .

Metode logit digunakan untuk mengatasi masalah variabel terikat yang bersifat kualitatif, yaitu untuk mengatahui faktor-faktor apa yang 
mempengaruhi petani dalam alih komoditi padi sawah ke perikanan, yaitu :

$\mathrm{K}=\log \left|\frac{\mathrm{P}_{1}}{1-\mathrm{Pi}}\right|=\log \beta_{0}+\log \beta_{1} \mathrm{LL}+\log \beta_{2} P D U P+\log \beta_{3} P P+\log \beta_{4} R U T$

Dimana :

$\mathrm{K} \quad=1$ keputusan petani beralih komoditi padi ke ikan, 0 jika petani tidak beralih komoditi

$\mathrm{Pi} \quad=$ Peluang keputusan petani $(0<\mathrm{P}<1)$

$\beta_{0} \quad=$ Koefisien Penduga

$\beta_{1}-\beta_{4}=$ Parameter Penduga

LL = Luas Lahan $(\mathrm{Ha})$

PDUP= Pendapatan dari Usahatani Ikan

(Rp/proses produksi)

JPP = Jumlah Produksi Padi $(\mathrm{Kg} /$ proses produksi)

RUT = Resiko Usahatani (kali/6 tahun terakhir)

Ketepatan model yang dirumuskan diketahui dengan cara melakukan analisis nilai statistik-F dengan mengajukan hipotesis:

Dimana:

$$
\mathrm{F}_{\text {hitung }}=\frac{\mathrm{JK} \text { regresi } /(\mathrm{k}-1)}{\mathrm{JK} \text { sisa } /(\mathrm{n}-1)}
$$

$\mathrm{K}$ = Jumlah Variabel

$\mathrm{n}=$ Jumlah Pengamatan Contoh

Kaidah Keputusan :

$\mathrm{HO}: \beta \mathrm{i} \leq 0$

$\mathrm{H} 1: \beta \mathrm{i}>0$

Bila $F_{\text {hitung }} \leq F_{\text {tabel }}$ diputuskan untuk menerima $\mathrm{H}_{0}$ yang berarti tidak berpengaruh signifikan variabel penjelas secara bersama-sama terhadap keputusan petani melakukan alih fungsi padi ke perikanan.

Bila $\mathrm{F}_{\text {hitung }}>\mathrm{F}_{\text {tabel}}$, maka diputuskan untuk menolak $\mathrm{H}_{0}$ yang berati bahwa variabel penjelas secara bersama-sama berpengaruh signifikan terhadap keputusan petani padi dalam melakukan alih komoditi padi sawah ke perikanan.

Untuk menganalisis koefisien-koefisien regresinya secara simultan akan diuji nisbah kemungkinan (Secara Uji chi-square pada metode OLS) yang menyebarkan khi-Kuadrat $\left(\mathrm{X}^{2}\right)$ dengan menggunakan derajat bebas ke hipotesis yang akan diuji adalah sebagai berikut:

$\mathrm{H}_{0}: \beta_{1}=\beta_{2}=$ $\beta_{\mathrm{k}}=0$

$\mathrm{H}_{1} \quad$ : minimal satu $\beta_{\mathrm{j}}=0(\mathrm{j}=1,2,3$,

Selanjutnya untuk mengetahui variabelvariabel penentu mana saja yang secara signifikan menentukan petani alih fungsi padi sawah ke perikanan dilakukan uji t-student dengan hipotesis yang diuji sebagai berikut:

Rumus perhitungan nilai yang digunakan adalah:

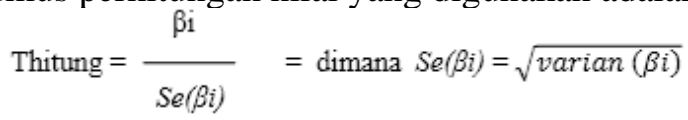

Dimana :

$\beta i=$ Koefisien regresi partial untuk variabel bebas ke $\mathrm{i}$

$\operatorname{Se}(\beta \mathrm{i})=$ Standar deviasi dari variabel bebas ke $\mathrm{i}$ Kaidah Keputusan :

$\mathrm{H}_{0}: \beta_{\mathrm{i}} \leq 0$

$\mathrm{H}_{1}: \beta_{\mathrm{i}}>0$

Apabila $\mathrm{T}_{\text {hitung }}>\mathrm{T}_{\text {tabel }}$ maka tolak $\mathrm{H}_{0}$. Hal ini berarti bahwa variabel penjelas secara partial berpengaruh secara signifikan terhadap variabel terikat.

Sebaliknya, apabila $\mathrm{T}_{\text {hitung }} \leq \mathrm{T}_{\text {tabel }}$ maka diputuskan untuk menerima $\mathrm{H}_{0}$. Hal ini berati bahwa secara partial variabel bebas tidak memberikan pengaruh atau perbedaan signifikan.

Untuk menjawab tujuan kedua, yaitu menghitung berapa besar perbedaan pendapatan petani setelah adanya alih fungsi komoditi padi sawah ke perikanan. Dengan melakukan perhitungan sebagai berikut :

$\mathrm{Pd}_{\mathrm{i}}=\mathrm{Pn}_{\mathrm{i}}-\mathrm{Btp}_{\mathrm{i}}$

$\mathrm{Pn}_{\mathrm{i}}=\mathrm{Y}_{\mathrm{i}} \cdot \mathrm{H}_{\mathrm{i}}$

$\mathrm{Btp}_{\mathrm{i}}=\mathrm{Bt}_{\mathrm{i}}+\mathrm{Bv}_{\mathrm{i}}$

Dimana :

$\mathrm{Pd}_{\mathrm{i}}=$ Pendapatan Usaha ke i (ikan,padi) $(\mathrm{Rp} / \mathrm{ha} / \mathrm{th})$

$\mathrm{Pn}_{\mathrm{i}}=$ Penerimaan Total ke i (ikan,padi) $(\mathrm{Rp} / \mathrm{ha} / \mathrm{th})$

$\mathrm{Btp}_{\mathrm{i}}=$ Biaya Total Produksi ke i (ikan,padi) (Rp/ha/th)

$\mathrm{Y}_{\mathrm{i}}=$ Jumlah produk yang dipasarkan ke $\mathrm{i}$ (ikan,padi) $(\mathrm{Kg} / \mathrm{ha})$

$\mathrm{H}_{\mathrm{i}}=$ Harga Produksi ke i (ikan,padi) $(\mathrm{Rp} / \mathrm{kg})$

$\mathrm{Bt}_{\mathrm{i}}=$ Biaya Total ke i (ikan,padi) $(\mathrm{Rp} / \mathrm{ha} / \mathrm{th})$

$\mathrm{Bv}_{\mathrm{i}}=$ Biaya Variabel ke i (ikan,padi) (Rp/ha/th)

Kemudian diuji dengan menggunakan rumus uji rangking Wilcoxon untuk mengetahui pendapatan mana yang paling menguntungkan.

Rumus uji rangking bertanda Wilcoxon

$$
Z=\frac{T-\mu_{T}}{\sigma_{T} \quad \sqrt{\frac{n(n+1)(2 n+1)}{24}}}=\frac{T-n(n+1) / 4}{\sqrt{2}}
$$

Dimana :

$$
\mu_{\mathrm{T}}=\frac{n(n+1)}{4} \mathrm{dan} \sigma_{\mathrm{T}}=\sqrt{\frac{n(\mathrm{n}+1)(2 \mathrm{n}+1)}{24}}
$$

Keterangan :

$\mathrm{Z}=\mathrm{Uji}$ ranking bertanda wilcoxon

$\mathrm{T}=\mathrm{T}_{\text {Hitung }}$ pendapatan

$\mu_{\mathrm{T}}=$ Median Pendapatan

$\sigma_{\mathrm{T}} \quad=$ Simpangan Baku

$\mathrm{n}=$ Jumlah Sampel 
Dengan hipotesis:

$\mathrm{H}_{0}$ : pendapatan rumah tangga petani padi sawah $>$ pendapatan ikan.

$\mathrm{H}_{1}$ : pendapatan rumah tangga petani padi sawah < pendapatan ikan.

\section{HASIL DAN PEMBAHASAN}

\section{A. Analisis Faktor-Faktor Penentu Rumah Tangga Petani Melakukan Alih Komoditi Padi Sawah ke Perikanan.}

Ada beberapa faktor penentu rumah tangga petani dalam melakukan alih komoditi dari padi sawah ke perikanan yaitu terdiri dari luas total kepemilikan lahan, pendapatan dari usahatani ikan, jumlah jumlah produksi padi, dan resiko kegagalan usahatani padi.

Tabel 4. Hasil Estimasi Koefisien Regresi dari Logit Keputusan Petani dalam Menentukan Alih Komoditi Padi Sawah ke Perikanan.

\begin{tabular}{llccccc}
\hline No & \multicolumn{1}{c}{ Variabel } & Koefisien & Wald & Sig & $\begin{array}{c}\text { Odds } \\
\text { Ratio }\end{array}$ & Ket \\
\hline 1 & Luas total kepemilikan lahan & 0,786 & 0,203 & 0,653 & 2,195 & Tn \\
2 & Pendapatan & 0,000 & 4,106 & 0,043 & 1,000 & $*$ \\
3 & Jumlah Produksi & $-0,001$ & 2,309 & 0,129 & 0,999 & $* *$ \\
4 & Resiko usahatani & 0,381 & 2,342 & 0,126 & 1,464 & $* *$ \\
\hline & Constant & $-1,591$ & 1,027 & 0,202 & 0,204 & \\
\hline
\end{tabular}

Sumber: Data Primer diolah, 2013.

$\mathrm{X}^{2}($ Chi-square $)=80,843$ dengan $\alpha 0,05$

$\mathrm{R}^{2}(\mathrm{R}$-square $)=87,3$

$* \quad=$ Berpengaruh nyata pada $\alpha=5 \%$

** $\quad=$ Berpengaruh nyata pada $\alpha=20 \%$

Tn $\quad=$ Tidak signifikan

Hasil analisis secara logit menunjukan bahwa nilai koefisien determinasi $\left(\mathrm{R}^{2}\right)$, yaitu 87,3 persen atau 0,873. Hal ini menunjukan bahwa 87,3 persen variasi keputusan petani dalam memilih untuk melakukan alih komoditi padi sawah ke perikanan dapat dijelaskan oleh faktor luas total kepemilikan lahan, pendapatan, jumlah produksi dan resiko usahatani. Sedangkan sisanya 12,7 persen dijelaskan oleh variabel lain yang tidak masuk dalam model penelitian seperti jarak lokasi ke sumber perairan, jarak sawah ke tempat tinggal petani, jumlah anggota keluarga, harga komoditi padi dan sebagainya. Secara statistik, nilai $\mathrm{X}^{2}$ hitung sebesar 80,843 dengan $\mathrm{p}$-value 0,000 dimana kurang dari $\alpha=0,05$ maka terbukti secara bersama-sama keempat variabel penentu mampu menjelaskan keputusan petani dalam memilih untuk melakukan alih komoditi padi sawah ke perikanan. Persamaan logit untuk hasil regresi sebagai berikut :

$\mathrm{Y}=\log \left|\frac{\mathrm{Pi}_{\mathrm{i}}}{1-\mathrm{Pi}_{\mathrm{i}}}\right|=-1,591+0,786 \mathrm{LL}+0,000 \mathrm{PDUP}-0,001 \mathrm{JPP}+0,381 \mathrm{RUT}$

Sementara itu, hasil uji parsial (Tabel 4) menunujukkan bahwa variabel signifikan pada taraf kepercayaan hingga $20 \%$ adalah variabel pendapatan usahatani $(4,3 \%)$, jumlah produksi padi $(12,9 \%)$, dan resiko usahatani $(12,6 \%)$. Keputusan petani untuk mengalihfungsikan lahan sawah ke perikanan di Desa Liman Sari dipengaruhi secara signifikan oleh faktor-faktor berikut:

\section{Luas Total Kepemilikan Lahan}

Persamaan regresi menunjukkan bahwa pengaruh luas total kepemilikan lahan sebesar 0,786 dan nilai odds ratio-nya sebesar 2,195 . Hal ini menunjukkan bahwa semakin besar luas total kepemilikan lahan, maka peluang petani untuk mengalihfungsikan lahan sebesar 0,786 kali dibandingkan tidak mengalih fungsikan lahannya. Dengan kata lain jika luas total kepemilikan lahan petani semakin tinggi dalam satu $\mathrm{m}^{2}$ maka akan menaikkan peluang keputusan petani untuk melakukan alih komoditi dari padi sawah ke perikanan sebesar 0,786 kali. Namun variabel luas lahan ini berpengaruh tidak nyata. Hal ini dapat dilihat dari nilai sign pada uji Wald yang nilai sign-nya sebesar 0,653 lebih besar dari nilai $\alpha=$ 0,20 . Hasil ini tidak sesuai dengan fakta di lapangan bahwa walaupun variabel luas kepemilikan lahan ini berpengaruh tidak nyata, namun petani yang melakukan alih komoditi padi sawah ke perikanan mempunyai luas lahan ratarata 1,06 hektar, lebih besar dibandingkan petani yang tidak melakukan alih komoditi yang hanya memiliki luas lahan rata-rata sebesar 0,68 hekter.

\section{Pendapatan}

Persamaan regresi menunjukkan bahwa variabel pendapatan petani sebesar 0,000 dan nilai Odds ratio-nya sebesar 1,000 . Hal ini menunjukkan bahwa semakin bertambah pendapatan petani maka peluang keputusan rumah tangga petani dalam alih komoditi padi sawah ke perikanan atau tidak melakukan alih komoditi adalah sama. Variabel pendapatan ini berpengaruh nyata terhadap keputusan petani untuk melakukan alih komoditi. Hal ini dapat dilihat dari nilai sign pada uji Wald yang nilai sign-nya sebesar 0,043 lebih kecil dari nilai $\alpha=$ 0,05 . Hasil analisis ini sesuai dengan keadaan di lapangan bahwa pendapatan yang diperoleh petani ikan lebih besar dari pada petani padi dan harga jual ikan lebih tinggi dibandingkan harga jual 
padi, sehingga pendapatan petani ikan akan bertambah dan akan mempengaruhi keputusan rumah tangga petani padi untuk melakukan alih komoditi padi sawahnya ke perikanan.

3. Jumlah Produksi Padi

Persamaan regresi menunjukkan bahwa pengaruh variabel jumlah produksi padi terhadap keputusan rumah tangga petani padi sawah ke perikanan sebesar -0,001 (dengan tanda negatif) dan nilai Odds ratio-nya 0,999 . Hal ini menunjukkan bahwa jika jumlah produksi semakin rendah satu kilogram maka peluang keputusan rumah tangga petani untuk melakukan alih komoditi dari padi sawah ke perikanan meningkat sebesar 0,001 kali, kemungkinan ini akan terjadi hingga produksi padi dapat meningkat sehingga pendapatan petani juga meningkat. Kemudian setelah diuji di dapat nilai sign sebesar 0,129 lebih besar dari $\alpha=0,20$ yang berarti variabel jumlah produksi padi berpengaruh nyata terhadap keputusan petani pada taraf uji 20\%. Hal ini sesuai dengan fakta di lapangan yang menunjukkan bahwa semakin rendah hasil produksi padi yang diperoleh petani, maka petani cenderung untuk melakukan alih komoditi.

\section{Resiko Usahatani}

Persamaan regresi menunjukkan bahwa pengaruh resiko usahatani terhadap keputusan rumah tangga petani untuk mengalihfungsikan lahan sawah padi ke perikanan adalah sebesar 0,381 dan nilai Odds ratio-nya 1,464 . Hal ini menunjukkan bahwa semakin sering petani mengalami kegagalan panen padi maka peluang keputusan rumah tangga petani untuk melakukan alih komoditi dari padi sawah ke perikanan akan naik sebesar 0,381 kali. Kemudian setelah di uji di dapat nilai sign sebesar 0,126 lebih besar dari nilai $\alpha=0,2$. Hal ini menunjukkan bahwa variabel resiko usahatani padi berpengaruh nyata terhadap keputusan petani padi sawah dalam melakukan alih fungsi ke perikanan pada taraf uji $20 \%$. Hal ini sesuai dengan hasil di lapangan bahwa seluruh petani contoh yang melakukan alih komoditi padi sawah ke perikanan pernah mengalami kegagalan panen lebih dari 3 kali dalam 6 tahun terakhir.

\section{B. Analisis Perbedaan Pendapatan Petani pada Sawah Keperikanan.}

\section{Usaha Padi}

\section{a.Biaya Produksi}

Berdasarkan hasil penelitian, luas lahan rata-rata yang dimiliki petani contoh petani contoh yang tidak melakukan alih komoditi padi sawah ke perikanan adalah sebesar 0,68 hektar. Luas lahan yang dimiliki ini semuanya digunakan untuk usahatani padi sawah. Data yang dianalisis adalah data usahatani padi selama 1 tahun yaitu pada musim tanam II (Maret - Oktober 2012) dan musim tanam I (Oktober 2012-Maret 2013).

Biaya produksi pada petani contoh yang tidak melakukan alih komoditi padi sawah ke perikanan yang dikeluarkan meliputi biaya tetap dan biaya variabel usahatani padi. Biaya tetapnya adalah cangkul, arit, alat penyiangan (gosrok), lory (gerobak dorong) handsprayer dan handtraktor. Sedangkan biaya variabelnya adalah tenaga kerja, benih, pupuk, dan pestisida. Untuk biaya tetap yang diperhitungkan adalah biaya penyusutan alat-alat pertanian.

Tabel 5. Rata-rata Biaya Produksi Petani Padi Contoh di Desa Liman Sari dengan Luas Garapan Rata-Rata 0,68 Hektar pada Musim Tanam II (Maret Oktober 2012) dan Musim Tanam I (Oktober 2012 - Maret 2013).

\begin{tabular}{|c|c|c|c|c|}
\hline \multirow{2}{*}{ No. } & \multirow{2}{*}{ Jenis Biaya } & \multicolumn{2}{|c|}{$\begin{array}{c}\text { Biaya Produksi Petani Padi } \\
\text { Rata-rata }\end{array}$} & \multirow{2}{*}{ Jumlah (Rp/th) } \\
\hline & & $\begin{array}{l}\text { Musim } \\
\text { Tanam II }\end{array}$ & $\begin{array}{c}\text { Musim Tanam } \\
\text { I }\end{array}$ & \\
\hline \multirow[t]{8}{*}{1.} & Biaya Tetap & & & \\
\hline & - Cangkul & $9.868,40$ & $9.868,40$ & $19.736,80$ \\
\hline & - Arit & $4.647,92$ & $4.647,92$ & $9.295,84$ \\
\hline & - Gosrok (Alat Penyiangan) & $3.031,25$ & $3.031,25$ & $6.062,50$ \\
\hline & - Lory (Gerobak dorong) & $7.855,99$ & $7.855,99$ & $15.711,98$ \\
\hline & - Handspprayer & $20.915,63$ & $20.915,63$ & $41.831,26$ \\
\hline & - Handtraktor & $72.615,28$ & $72.615,28$ & $145.230,56$ \\
\hline & Total Biaya Tetap & $86.829,18$ & $86.829,18$ & $173.658,36$ \\
\hline \multirow[t]{11}{*}{2.} & Biaya Variabel & & & \\
\hline & - Biaya Benih & 205.368 & 205.368 & $410.736,00$ \\
\hline & - Biaya Pupuk Urea & 257.237 & 299.684 & $556.921,00$ \\
\hline & - Biaya Pupuk SP-36 & 160.789 & 150.526 & $311.315,00$ \\
\hline & - Biaya Pupuk NPK & 230.921 & 188.286 & $419.207,00$ \\
\hline & - Biaya Herbisida & 170.526 & 160.000 & $330.526,00$ \\
\hline & - Biaya Fungisida & 261.053 & 176.842 & $437.895,00$ \\
\hline & - Biaya Insektisida & 322.105 & 345.263 & $667.368,00$ \\
\hline & - Biaya Tenaga Kerja & $3.694 .842,11$ & 4.086 .979 & $7.781 .821,11$ \\
\hline & Total Biaya Variabel & 5.302 .842 & 5.612 .948 & $10.915 .790,00$ \\
\hline & Rata-rata Biaya Produksi & $5.389 .671,29$ & $5.699 .781,72$ & $11.089 .453,01$ \\
\hline
\end{tabular}

Sumber: Data Primer diolah, 2013.

Berdasarkan tabel diatas, rata-rata biaya penyusutan alat yang dikeluarkan petani contoh pada usahatani padi adalah sebesar Rp 173.658,36 per tahun. Hal tersebut terjadi karena berbedanya lama umur ekonomis alat pertanian untuk masingmasing petani, daya beli petani terhadap alat yang akan di gunakan seperti traktor, selain itu harga beli alat untuk masing-masing petani juga berbeda. Rata-rata biaya variabel usahatani padi sebesar 10.915.790,00 per tahun yang terdiri atas biaya pemupukan adalah sebesar Rp 1.287.443,per tahun, pestisida sebesar Rp 1.435.789,- per tahun, dan tenaga kerja sebesar Rp 7.781.821,11 
per tahun, serta biaya benih Rp 410.736,00 per per tahun, sehingga total biaya produksi yang dikeluarkan untuk usahatani padi adalah sebesar Rp. 11.089.453,01.

\section{b. Produksi, Penerimaan, dan Pendapatan}

Penerimaan petani contoh padi diperoleh dari jumlah produksi padi dikali harga jual padi di pasar. Pendapatan petani padi merupakan total penerimaan dari usaha tani padi dikurangi dengan total biaya produksi padi yang dikeluarkan petani.

Tabel 6. Rata-Rata Produksi, Penerimaan dan Pendapatan Petani Padi Contoh di Desa Liman Sari dengan Luas Garapan Rata-Rata 0,68 Hektar pada Musim Tanam II (Maret-Oktober 2012) dan Musim Tanam I (Oktober 2012-Maret 2013)

\begin{tabular}{|c|c|c|c|c|}
\hline \multirow{2}{*}{ No. } & \multirow{2}{*}{ Uraian } & \multicolumn{2}{|c|}{$\begin{array}{c}\text { Rata-Rata Produksi Padi } \\
\text { Gabah Kering Panen (GKP) }\end{array}$} & \multirow{2}{*}{$\begin{array}{l}\text { Jumlah (per } \\
\text { Th) }\end{array}$} \\
\hline & & $\begin{array}{l}\text { Musim Tanam } \\
\text { II }\end{array}$ & $\begin{array}{l}\text { Musim } \\
\text { Tanam I }\end{array}$ & \\
\hline 1. & Produksi (Kg/ha/th) & 3.422 & 4.443 & 7.865 \\
\hline 2. & Harga Jual (Rp/kg) & 3.695 & 3.541 & - \\
\hline 3. & Penerimaan $(\mathrm{R} p)$ & 12.663 .368 & 15.695 .694 & 28.359 .062 \\
\hline 4. & Biaya Produksi (Rp) & 5.389 .671 & 5.699 .782 & 11.089 .453 \\
\hline 5. & Pendapatan $(R p)$ & 7.273 .697 & 9.995 .912 & 17.269 .609 \\
\hline
\end{tabular}

Sumber : Data Primer diolah, 2013.

Berdasarkan tabel diatas, rata-rata produksi yang dihasilkan oleh petani padi pada luasan ratarata adalah sebesar $7.865 \mathrm{~kg}$ per tahun. Ratarata harga jual padi pada musim tanam I sebesar Rp.3.695,- per kg dan harga pada musim tanam II adalah sebesar $\mathrm{Rp} 3.541$ per $\mathrm{kg}$, maka diperoleh penerimaan rata-rata sebesar Rp. 28.359.062,per tahun sehingga rata-rata pendapatan yang diperoleh petani padi adalah sebesar $\mathrm{Rp}$. 17.269.609,- per tahun.

\section{Usahatani Ikan Patin}

\section{a.Biaya Produksi}

Berdasarkan hasil penelitian, rata-rata luas lahan total yang dimiliki petani contoh yang melakukan alih komoditi padi sawah ke perikanan adalah sebesar 1,06 hektar. Luas lahan yang dimiliki ini tidak semuanya digunakan untuk usahatani ikan patin. Luas lahan yang dialihfungsikan hanya sebesar 0,63 hektar atau 59 persennya saja, sehingga data yang dianalisis adalah data usahatani ikan patin seluas 0,63 hektar. Dari hasil penelitian, diperoleh data bahwa lama masa produksi ikan patin adalah 6-8 bulan.
Biaya produksi yang dikeluarkan pada petani contoh yang melakukan alih komoditi padi sawah ke perikanan meliputi biaya tetap dan biaya variabel budidaya ikan. Biaya tetapnya adalah pompa air diesel, ember, alat pengangkut/rolly. Sedangkan biaya variabelnya adalah tenaga kerja, benih ikan patin, pakan, kapur, obat-obatan, garam. Biaya tetap yang diperhitungkan adalah biaya penyusutan alat-alat pertanian. Rata-rata biaya produksi yang dikeluarkan petani ikan pada luasan 0,63 selama 6 bulan.

Tabel 7. Rata-rata Biaya Produksi Usahatani Ikan Patin pada Luas Lahan Rata-Rata 0,63 Hektar di Desa Liman Sari, 2013.

\begin{tabular}{llr}
\hline \multicolumn{1}{c}{ Nenis Biaya } & \multicolumn{2}{c}{$\begin{array}{c}\text { Biaya Produksi Petani Ikan } \\
\text { Rata-rata(Rp/Th) }\end{array}$} \\
\hline 1. & Biaya Tetap & 103.509 \\
& - Pompa Air Diesel & 1.209 \\
- Ember & 10.508 \\
- Alat Pengangkut/Rolly & 115.226 \\
\hline Total Biaya Tetap & \\
\hline 2. Biaya Variabel & 9.270 .000 \\
- Biaya Bibit & 71.053 \\
- Biaya Kapur & 89.737 \\
- Biaya Garam & 654.474 \\
- Biaya Obat-Obatan & 59.695 .816 \\
- Biaya Pakan & 12.862 .895 \\
\hline - Biaya Tenaga Kerja & 82.643 .974 \\
\hline Total Biaya Variabel & $82.759 .200,18$ \\
\hline Total Biaya Produksi &
\end{tabular}

Sumber : Data Primer diolah, 2013.

Berdasarkan tabel diatas rata-rata biaya penyusutan alat yang dikeluarkan petani contoh pada budidaya ikan adalah sebesar Rp 115.226 per proses produksi (6 bulan). Hal tersebut terjadi karena berbedanya lama umur ekonomis alat pertanian untuk masing-masing petani, selain itu harga beli alat untuk masing-masing petani juga berbeda. Rata-rata biaya variabel usahatani ikan patin adalah sebesar Rp.82.643.974,- yang terdiri atas biaya kapur adalah sebesar Rp 71.053 per proses produksi, tenaga kerja sebesar Rp 12.862.895 per proses produksi, bibit ikan sebesar Rp 9.270.000 per proses produksi, pakan sebesar Rp 59.695.816 per proses produksi, obat-obatan sebesar Rp.654.474 per proses produksi, dan garam sebesar Rp 89.737 per proses produksi, sehingga total biaya produksi yang dikeluarkan untuk usahatani ikan patin adalah sebesar Rp. 82.759.200,18,--

b. Produksi, Penerimaan, dan Pendapatan

Penerimaan petani yang melakukan alih komoditi padi sawah ke budidaya ikan patin diperoleh dari jumlah produksi ikan dikali harga jual ikan di pasar. Pendapatan petani yang melakukan alih komoditi padi sawah ke perikanan, merupakan total penerimaan ikan dikurangi 
dengan total biaya produksi ikan yang dikeluarkan petani.

Tabel 8. Rata-Rata Produksi, Penerimaan dan Pendapatan Usahatani Ikan Patin pada Luas Lahan Rata-Rata 0,63 Hektar di Desa Liman Sari, 2013.

\begin{tabular}{clr}
\hline No. & \multicolumn{1}{c}{ Uraian } & Rata-rata Ikan \\
\hline 1. & Produksi (Kg/proses & $11.941,05$ \\
2. & Haduksi) & 13.145 \\
& $\begin{array}{l}\text { Penerimaan } \\
\text { 3. }\end{array}$ & 156.927 .368 \\
(Rp/proses produksi) & Biaya Produksi & $82.759 .200,18$ \\
4. & $\begin{array}{l}\text { (Rp/proses produksi) } \\
\text { 5. }\end{array}$ & Pendapatan \\
(Rp/proses produksi) & 74.168 .168 \\
\hline
\end{tabular}

Sumber : Data Primer diolah, 2013.

Berdasarkan tabel diatas, rata-rata produksi yang dihasilkan oleh petani ikan ratarata produksi yang dihasilkan adalah sebesar $11.941,05 \mathrm{~kg}$ per proses produkis. Rata-rata harga jual ikan adalah sebesar Rp 13.145 per $\mathrm{kg}$, sehingga petani ikan diperoleh penerimaan ratarata adalah sebesar Rp 156.927.368,- per proses produksi. Oleh karena itu dalam satu kali proses (6 bulan) dengan luas garapan rata-rata 0,63 hektar petani ikan memperoleh pendapatan ratarata sebesar $\quad \operatorname{Rp} 74.168 .168,-$.

Perbedaan pendapatan diperoleh dari selisih rata-rata produksi, penerimaan, pendapatan, biaya produksi, harga jual dari petani padi sawah yang tidak melakukan alih komoditi dan petani padi yang melakukan alih komoditi ke ikan.

Tabel 9. Rata- Rata Selisih Produksi, Penerimaan, Pendapatan, Biaya Produksi, Harga Jual Petani Padi Sawah dan Ikan di Desa Liman Sari.

\begin{tabular}{|c|c|c|c|c|c|c|c|}
\hline \multirow{3}{*}{ No } & \multirow{3}{*}{ Uraian } & \multicolumn{6}{|c|}{ Rata-rata } \\
\hline & & \multicolumn{2}{|c|}{$\begin{array}{c}\text { Padi } \\
\text { Gabah Kering Panen } \\
\text { (GKP) }\end{array}$} & \multicolumn{2}{|c|}{ Ikan Patin } & \multicolumn{2}{|c|}{ Selisih } \\
\hline & & $\begin{array}{l}\text { Per Luas } \\
\text { Garapan }\end{array}$ & $\begin{array}{c}\text { Per } \\
\text { Hektar }\end{array}$ & $\begin{array}{l}\text { Per Luas } \\
\text { Garapan }\end{array}$ & $\begin{array}{c}\text { Per } \\
\text { Hektar }\end{array}$ & $\begin{array}{l}\text { Per Luas } \\
\text { Garapan }\end{array}$ & $\begin{array}{c}\text { Per } \\
\text { Hektar }\end{array}$ \\
\hline 1 & $\begin{array}{l}\text { Produksi } \\
\text { (Kg/Tahun) }\end{array}$ & 7.865 & 11.469 & $11.941,05$ & $19.357,54$ & 4.076 & $7.888,54$ \\
\hline 2 & $\begin{array}{l}\text { Harga Jual } \\
\text { (Rp/kg) }\end{array}$ & 3.618 & 3.618 & 13.145 & 13.145 & 9.527 & 9.527 \\
\hline 3 & $\begin{array}{l}\text { Penerimaan ( } \mathrm{Rp} / \\
\text { Tahun) }\end{array}$ & $\begin{array}{r}28.359 .06 \\
2\end{array}$ & 41.375 .776 & $\begin{array}{r}156.927 .36 \\
8\end{array}$ & $\begin{array}{r}254.445 .08 \\
8\end{array}$ & $\begin{array}{r}128.568 .30 \\
6\end{array}$ & $\begin{array}{r}213.069 .31 \\
2\end{array}$ \\
\hline 4 & $\begin{array}{l}\text { Biaya Produksi } \\
\text { (Rp/ Tahun) }\end{array}$ & $\begin{array}{r}11.089 .45 \\
3\end{array}$ & 16.220 .985 & 82.759 .200 & $\begin{array}{r}134.456 .65 \\
5\end{array}$ & 71.669 .747 & $\begin{array}{r}118.235 .67 \\
0\end{array}$ \\
\hline 5 & $\begin{array}{l}\text { Pendapatan (Rp/ } \\
\text { Tahun) }\end{array}$ & $\begin{array}{r}17.269 .60 \\
9\end{array}$ & 25.154 .791 & 74.168 .168 & $\begin{array}{r}119.988 .43 \\
3\end{array}$ & 56.898 .559 & 94.833 .642 \\
\hline
\end{tabular}

Sumber : Data Primer diolah, 2013.

Berdasarkan tabel diatas rata-rata produksi yang dihasilkan oleh petani padi sawah sebesar 47.865 kilogram per tahun, sedangkan petani ikan rata-rata produksi yang dihasilkan sebesar 11.941,05 kilogram per proses produksi. Selisih rata-rata hasil produksi padi sawah dan ikan yaitu sebesar 4.076 kilogram.
Rata-rata harga jual padi Rp 3.618 per kilogram. Rata-rata harga jual ikan Rp 13.145 per kilogram. Harga jual ikan yang lebih tinggi dibandingkan padi dikarenakan biaya yang di keluarkan untuk budidaya ikan juga tinggi. Selisih rata- rata harga jual padi dan ikan yaitu sebesar Rp 9.527 per kilogram.

Rata-rata dari penerimaan keseluruhan yang diperoleh oleh petani padi sebesar Rp 28.359.062 per tahun. Sedangkan penerimaan keseluruhan petani ikan sebesar Rp 156.927.368 per tahun. Jadi penerimaan ikan lebih besar dibandingkan padi. Hal ini disebabkan harga ikan lebih tinggi dan biaya yang dikeluarkan untuk budidaya ikan juga lebih tinggi dari pada padi. Selisih rata-rata total penerimaan petani padi sawah dan ikan yaitu sebesar Rp 128.568.306 per tahun.

Rata-rata biaya produksi yang dikeluarkan petani padi sawah sebesar Rp 11.089.453 per tahun. Sedangkan biaya produksi yang dikeluarkan petani ikan sebesar Rp 82.759.200,18 per tahun. Selisih rata-rata total biaya produksi yang dikeluarkan petani padi sawah dan ikan yaitu sebesar Rp 71.669.747 per tahun.

Rata-rata pendapatan yang diperoleh petani padi sawah sebesar Rp 17.269.609 per tahun. Sedangkan pendapatan yang diperoleh oleh petani ikan adalah sebesar Rp 74.168.168,- per tahun. Selisih rata-rata total pendapatan petani padi sawah dan ikan yaitu sebesar $\mathrm{Rp}$ 56.898.559,-. Rata-rata pendapatan ikan lebih besar dari pada pendapatan padi. Hal ini menunjukkan bahwa berbudidaya ikan lebih menguntungkan dari pada bertani padi.

Selisih rata-rata produksi, penerimaan, pendapatan, biaya produksi, harga jual dari petani padi sawah yang tidak melakukan alih komoditi dan petani padi yang melakukan alih komoditi padi ke ikan diperoleh dari perhitungan selama satu tahun pada luas satu hektar. Masa produksi untuk usahatani padi dihitung dua kali produksi dalam satu tahun, sedangkan usahatani ikan patin hanya satu kali dalam satu tahun. Hal ini dikarenakan walaupun proses produksi ikan patin adalah enam bulan, namun setelah produksi pertama tidak dapat langsung ditebar benih kembali. Penebaran benih atau proses produksi selanjutnya dilaksanakan setelah dilakukan pengeringan kolam dan olah tanah yang memakan waktu kurang lebih dua bulan. Pengeringan kolam bertujuan untuk memutus rantai hama dan penyakit.

Setelah dianalisis menggunakan analisis uji tanda Wilcoxon di dapat nilai $Z_{\text {hitung }}=-5,373<$ $\mathrm{Z}_{\text {tabel }}$ dengan $\mathrm{p}$ value (Asymp sign 2 tailed) = 
0,000 dimana kurang dari nilai kritis penelitian 0,05 hal ini menunjukkan bahwa pendapatan petani yang melakukan alih komoditi ke usahatani ikan patin lebih besar yaitu Rp 94.833.642,- per tahun per hektar dibandingkan pendapatan padi sawah yang tidak melakukan alih komoditinya yaitu Rp 25.154.791,- per tahun per hektar.

Berdasarkan hasil pengamatan, walaupun usahatani ikan patin di Desa Liman Sari memberikan keuntungan yang lebih besar dibandingkan dengan usahatani padi namun tidak semua petani di Desa Liman Sari melakukan alih komoditi padi sawah ke perikanan. Hal ini dikarenakan biaya yang dibutuhkan dalam usahatani ikan patin sangat tinggi, sehingga petani lebih memilih usahatani padi yang biaya produksinya relaif lebih rendah.

\section{IV.KESIMPULAN DAN SARAN}

\section{A. Kesimpulan}

Berdasarnya hasil penelitian dan analisis yang telah dilakukan, maka dapat ditarik kesimpulan sebagai berikut:

1. Faktor yang mempengaruhi keputusan rumah tangga petani dalam melakukan alih komoditi padi sawah ke perikanan pada taraf uji sampai $20 \%$ yaitu pendapatan petani $(4,3 \%)$, jumlah produksi (12,9\%) dan resiko usahatani (12,6\%), sedangkan luas lahan yang dimiliki berpengaruh tidak nyata.

2. Hasil analisis statistik dengan menggunakan analisis uji tanda Wilcoxon, didapat nilai $Z_{\text {hitung }}$ $=-5,373<\mathrm{Zt}_{\text {abel }}$ dengan $\mathrm{p}$ value (Asymp sign 2 tailed) $=0,000$ dimana kurang dari nilai kritis penelitian 0,05. Hal ini menunjukkan bahwa pendapatan petani yang melakukan alih komoditi padi sawah ke usahatani ikan patin lebih besar yaitu Rp 94.833.642,- per tahun per hektar dibandingkan pendapatan usahatani padi sawah yang tidak melakukan alih fungsi lahannya yaitu Rp 25.154.791,- per tahun per hektar.

\section{B.Saran}

1. Penelitian berikutnya dapat memasukkan beberapa variabel lain contohnya variabel sosial yang diduga dapat mempengaruhi alih fungsi lahan.

2. Meskipun pendapatan petani dari usahatani ikan cukup tinggi namun kepada Pemerintah Daerah Kabupaten OKU Timur perlu melakukan kebijakan pengendalian alih fungsi lahan pertanian sawah menjadi perikanan dengan partisipasi dari keseluruhan stakeholders untuk mencegah alih fungsi lahan yang tidak terkendali.

3. Harus ada sosialisasi terkait dengan adanya peraturan sehingga masyarakat juga akan ikut terlibat.

\section{DAFTAR PUSTAKA}

Anonim. 2009. Undangan-Undang Republik Indonesia Nomor 41 Tahun 2009 tentang Perlindungan Lahan Pertanian Pangan Berkelanjutan.

Ario, 2010. Analisis Peranan Sektor Pertanian Terhadap Perekonomian Jawa Tengah (Pendekatan Analisis Input-Output). Skripsi. Fakultas Ekonomi. Universitas Diponegoro. (Tidak Dipublikasikan).

Hernanto, F. 1989. Ilmu Usahatani. Penebar Swadaya. Jakarta.

Kurdianto, D. 2012. Alih Fungsi Lahan Pertanian Sawah ke Tanaman Kelapa Sawit. Biologi - 09 UIR.....saLaM BioLogi, Diakses 15 Februari 2013.

Nasir. 2009. Metode Penelitian Ilmiah. Mandar Maju. Bandung

Saili, I, dan H. Purwadio. 2012. Pengendalian Alih Fungsi Lahan Pertanian Sawah Menjadi Perkebunan Kelapa Sawit di Wilayah Kabupaten Siak-Riau. Jurnal Teknik Perencanaan Wilayah dan Kota. Vol.1, No.1, (2012)1-3. Fakultas Teknik Sipil dan Perencanaan ITS. Surabaya.

Siegel, 1997. Statistik Non Parametrik Untuk Ilmu-ilmu Sosial. Gramedia Pustaka Utama, Bandung.

Soekartawi, Dillon JL, Hardaker JB, Soeharjo A. 1986. Ilmu Usahatani dan Penelitian Untuk Perkembangan Petani Kecil. Universitas Indonesia Press. Jakarta.

Soekartawi. 2002. Analisis Usahatani. UI Press. Jakarta

Sumardjono. D. 2004. Diktat Kuliah Ekonomi Produksi. Program Study Sosial Ekonomi Peternakan. Fakultas Peternakan Universitas Diponegoro. Semarang.

Sumarwan, U. 2004. Perilaku Konsumen Teori Dan Penerapannya Dalam Pemasaran . Ghalia Indonesia. Bogor.

Suratiyah, K. 2009. Ilmu Usahatani. Penebar swadaya. Jakarta.

Utomo, M., Eddy Rifai dan Abdulmutalib Thahir. 1992. Pembangunan dan Alih Fungsi Lahan. Lampung: Universitas Lampung. 
Yuliansyah, Dedi \& Ketut, Sukiyono \& Antoni, Sitorus. 2012. Analisis Alih Fungsi Lahan Sawah ke Lahan Perikanan Darat sebagai Respon Kebijakan Pengembangan Minapolitan di Kabupaten Bengkulu Utara Provinsi Bengkulu (Studi Kasus di
Kecamatan Padang Jaya). Master Tesis. (Tidak Dipublikasikan). Universitas Bengkulu. 